Reprod. Nutr. Dévelop., 1980, 20 (3 A), 709-717.

\title{
Effect of induced hypothalamic hyperphagia and forced-feeding on organ weight and tissular development in Landes geese
}

\author{
par Bernadette FELIX, P. AUFFRAY, J. C. MARCILLOUX \\ with the technical assistance of L. ROYER \\ Laboratoire de Physiologie de la Nutrition, I. N. R. A., \\ 78350 Jouy-en-Josas, France.
}

\begin{abstract}
Summary. The effects of induced hypothalamic hyperphagia and forced-feeding were studied in 30 geese of the Landes breed. They were housed in individual cages under a darklight cycle of $12 \mathrm{hrs}$ light-12 hrs darkness. Eleven geese with ventromedian hypothalamic (VMH) lesions and 8 controls were fed ad libitum. A third lot of 11 force-fed animals was pair-fed with the operated geese. The study lasted 4 weeks after an adaptation period to the new environmental conditions. The daily food intake of the geese and their weekly liveweight gain were monitored. After VMH lesions, the mean food intake of the geese increased by 169 p. 100 so that after each treatment their liveweight increased and they became obese $(P<0.001)$. The tissue distribution of the group with lesions showed a higher amount of subcutaneous fat $(P<0.05)$, while the mesenteric fat $(P<0.05)$ was more abundant after forced-feeding. The liver weight was much higher in all cases; its increment reached 311 p. 100 in geese with VMH lesions and 193 p. 100 in the force-fed. However, those values were too low when compared to the means obtained by traditional forcedfeeding. Hyperphagia in the geese was very marked as compared to that in rats, but it was insufficient to produce a considerable hepatic steatosis.
\end{abstract}

\section{Introduction.}

The nervous system, and especially the hypothalamus, plays a large role in the control of food intake. It also intervenes in the mobilization, utilization and storage of fats in the organism. The ventromedian hypothalamic nuclei (VMH) are implicated in the regulation of these processes. As early as 1940, Hetherington and Ranson showed that bilateral electrolytic lesions of the $\mathrm{VMH}$ in laboratory rats caused some behavioral deviations ; one of these was increased food intake with the development of obesity.

While much work has been done in rats, research in birds is more recent and rare. It has been shown that birds (Feldman ef al., 1973), and particularly geese (Auffray and Blum, 1970), have the same symptoms after destruction of the mediobasal hypothalamic area. Such physiological modifications as functional castration, hyperphagia, rapid liveweight gain, marked obesity and the characteristic appearance of a dynamic then a static phase and hepatic steatosis have been reported. In the chicken, Lepkovsky and Yasuda (1966) emphasized the effect of mediobasal hypothalamic lesions on growth and body composition. Snapir ef al. (1976) showed the involvement of the hypothalamus and the septal area in the control of food intake and liveweight in geese. 
The forced-feeding technique is traditionally used to obtain fatty liver (Fleuret, 1953 ; Leclercq ef al., 1968), but is also produces lipid accumulation in storage tissues (Labie and Tournut, 1970). Thus, hyperphagia induced by lesions or by cramming causes marked changes in lipid metabolisms. Considering the economic importance of forced-feeding and the potentialities of the practical application of induced hyperphagia, and since there are no data in the literature, we were motivated to compare the effects of each of these treatments on the development of some tissues and organs in the goose.

\section{Material and methods.}

Animals and food intake. - Sixty-four 6 to 9-month old geese of the Landes breed from the Artiguères Esperimental Station were used. They were put into individual cages under a 12/12 light-dark cycle and fed a semi-liquid diet ( 1 part of meal to 2 of water) ad libitum containing 18 p. 100 proteins and 9 p. 100 lipids, supplying 4742 calories per $\mathrm{kg}$ of dry matter.

The geese were divided into three groups, including 8 controls, 28 birds with VMH lesions and 28 force-fed birds. The amount of dry food given to the force-fed in 3 meals every $24 \mathrm{hrs}$, as in traditional cramming, was based on the quantity of dry food ingested spontaneously in $24 \mathrm{hrs}$ by the hyperphagic geese 2 days before.

Four of the traditionally force-fed geese died as a result of cramming accidents (choking). Thirteen of the hyperphagics were discarded because the VMH had been

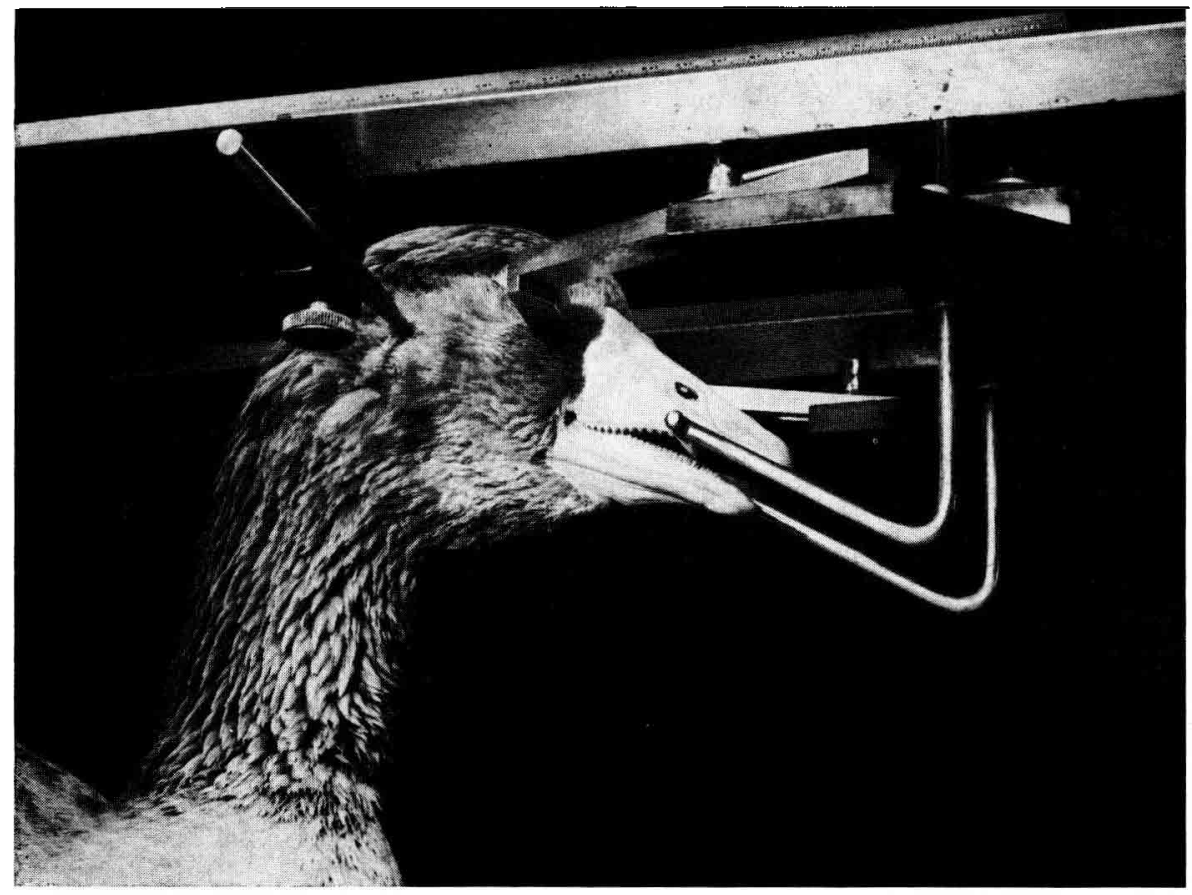

PHOTO 1. - Goose in the stereotaxic apparatus modified by Auffray. 
The carcasses were dissected so as to separate the external fat (skin + subcutaneous) and internal fat (abdominal + mesenteric), muscles and bones ; these different fractions as well as the intestine without the cloaca, were weighed. The fresh weight of the emptied intestine, the liver without gall bladder, the heart drained of blood, the pancreas, thyroid and adrenal glands was also determined. To maintain an homogeneity in the expression of the data and for purposes of comparison with already existent findings, the results of this study are given is percentages of liveweight. The data were compared by analysis of variance (F-test).

\section{Results.}

1. Food intake and liveweight gain. - Figure 1 shows that the amounts of food ingested daily increased immediately after $\mathrm{VMH}$ destruction. The dynamic phase continued up to day 15. Daily food intake then decreased gradually. Table 1 shows that the geese

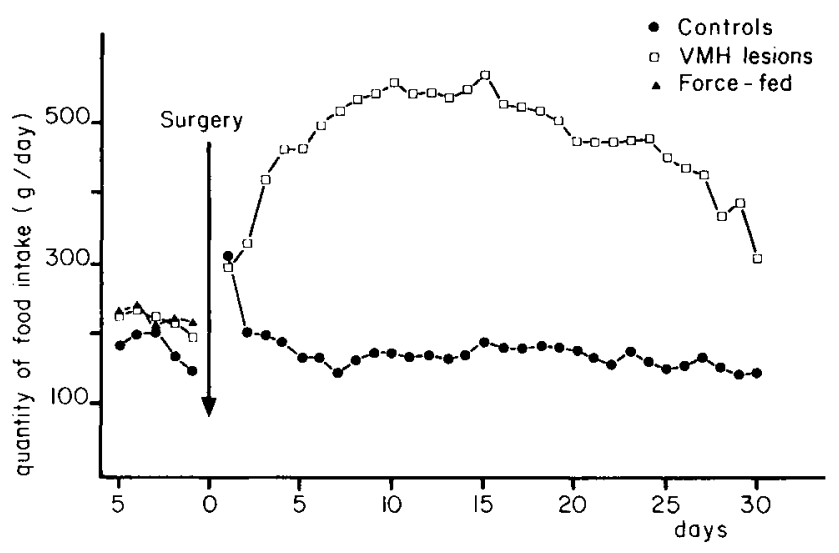

FIG. 1. - Food intake patferns of VMH-hyperphagic and control geese.

TABLE 1

Effect of hypothalamic hyperphagia and of forced-feeding on mean food intake and liveweight gain of geese (mean $\pm \mathrm{SE}$ )

\begin{tabular}{|c|c|c|c|c|}
\hline \multirow[b]{2}{*}{ Parameters measured } & \multicolumn{4}{|c|}{ Animals } \\
\hline & Control & $\begin{array}{c}\text { VMH- } \\
\text { lesioned }\end{array}$ & Force-fed & $\begin{array}{l}\text { Statistical } \\
\text { significance }\end{array}$ \\
\hline $\begin{array}{l}\text { Mean food intake in } \mathrm{g} / \text { day } / \text { goose } \\
5 \text { preoperative days } \ldots \ldots \ldots \ldots \ldots \ldots \ldots \\
30 \text { postoperative days........... }\end{array}$ & $\begin{array}{l}181 \pm 22 \\
175 a \pm 29\end{array}$ & $\begin{array}{l}221 \pm 15 \\
471^{\circ} \pm 74\end{array}$ & $\begin{array}{l}225 \pm 11 \\
471^{\circ} \pm 74\end{array}$ & $\underset{* * *}{N S}$ \\
\hline $\begin{array}{l}\text { Initial liveweight }(\mathrm{g}) \ldots \ldots \ldots \ldots \ldots \ldots \\
\text { Final liveweight }(\mathrm{g}) \ldots \ldots \ldots \ldots \ldots \ldots \\
\text { Liveweight gain }(\mathrm{g}) \ldots \ldots \ldots \ldots \ldots \ldots\end{array}$ & $\begin{aligned} 5411 & \pm 641 \\
5526^{a} & \pm 676 \\
115^{a} & \pm 354\end{aligned}$ & $\begin{array}{l}5492 \pm 735 \\
7445 b \pm 887 \\
1953 b \pm 462\end{array}$ & $\begin{array}{l}5374: \pm 552 \\
7130 b \pm 696 \\
1756^{b} \pm 434\end{array}$ & $\begin{array}{l}\text { NS } \\
* * * \\
* * *\end{array}$ \\
\hline
\end{tabular}

$* * * P<0.01$.

$a$, $b$ Values having the same letter are not statistically different.

NS Non-significant. 
with $\mathrm{VMH}$ lesions were clearly hyperphagic since their mean food intake increased by 169 p. 100.

The liveweight gain pattern was similar in both groups of treated animals (fig. 2). The curves showed no statistical differences during the 30 esperimental days. On the other hand, at the end of that period, liveweight appeared to be significantly higher than in the control groups, but of the same order of magnitude after each treatment.

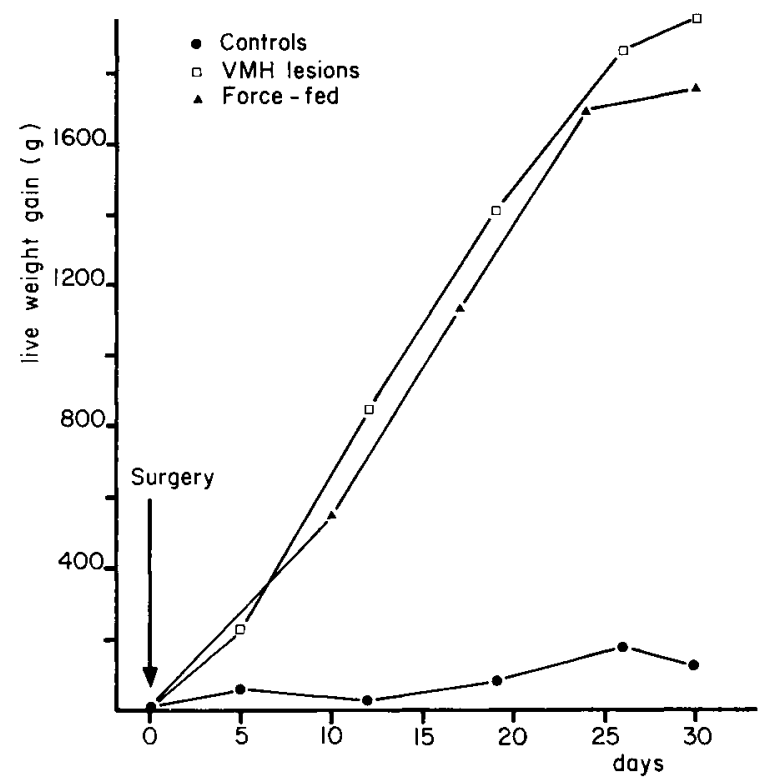

FIG. 2. - Cumulated liveweight gain patterns of control, VMH-hyperphagic and force-fed geese.

TABLE 2

Effect of hypothalomic hyperphagia and of forced-feeding on body tissue distribution (p. 100 of liveweight) of geese

\begin{tabular}{|c|c|c|c|c|}
\hline \multirow[b]{2}{*}{ Parameters measured } & \multicolumn{4}{|c|}{ Animals } \\
\hline & Control & VMH-lesioned & Force-fed & $\begin{array}{l}\text { Statistical } \\
\text { significance }\end{array}$ \\
\hline 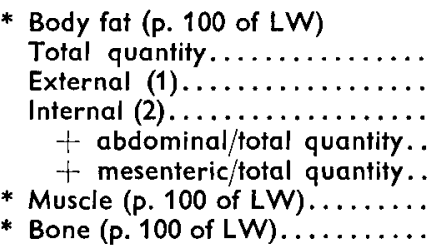 & $\begin{array}{r}31 a \pm 4.82 \\
21.46^{a} \pm 2.18 \\
9.54^{a} \pm 2.99 \\
0.17 \pm 0.03 \\
0.14^{a} \pm 0.03 \\
26^{a} \pm 3.04 \\
13.41^{a} \pm 2.81\end{array}$ & $\begin{array}{r}42^{b} \pm 6.19 \\
28.66^{b} \pm 3.36 \\
13.34^{b} \pm 2.33 \\
0.18 \pm 0.03 \\
0.16^{a} \pm 0.02 \\
22^{b} \pm 5.31 \\
10.47^{b} \pm 1.31\end{array}$ & $\begin{array}{r}40^{b} \pm 3.82 \\
25.42^{c} \pm 2.99 \\
14.58^{b} \pm 1.93 \\
0.19 \pm 0.02 \\
0.18^{b} \pm 0.03 \\
23^{a b} \pm 1.67 \\
10.74^{b} \pm 0.92\end{array}$ & $\begin{array}{c}* * * \\
* \\
* * * \\
N S \\
* \\
* \\
*\end{array}$ \\
\hline
\end{tabular}

LW : liveweight. teric fat.

(1) + external fat : skin + subcutaneous cover fat, (2) + internal fat : abdominal fat + mesen-

$a, b, c$ : Values having the same letter are not significantly different.

*** $P<0.001$, * $P<0.05$, NS Non-significant. 
2. Effect of treatment on tissue distribution. - Table 2 presents the whole of the weights of the different body fractions. The total quantity of fat increased in operated and force-fed geese by 35 and 29 p. 100, respectively, as compared to the control lot. Treatment effect on external fat was more evident because significant increases were found (34 p. 100 after lesion and 18 p. 100 after forced-feeding). On the other hand, forced-feeding enhanced internal fat development which increased by 53 p. 100 as against 40 p. 100 in lesioned birds when compared to the control group.

The percentages of muscle and bone in relation to liveweight were significantly lower in operated geese, thus showing a certain stability of the absolute value.

3. Effect of treatment on organ weights. - Ponderal liver gain was considerable during the experiment : 193 p. 100 in force-fed birds and 311 p. 100 in operated ones. The weight of the intestine, heart and pancreas did not vary in the three lots. On the other hand, thyroid weight decreased in the force-fed animals, while the adrenals weighed less after $\mathrm{VMH}$ lesion.

TABLE 3

Effect of hypothalomic hyperphagia and of forced-feeding on the relative weight (p. 100 of liveweight) of some organs

\begin{tabular}{|c|c|c|c|c|}
\hline \multirow[b]{2}{*}{ Parameters measured } & \multicolumn{4}{|c|}{ Animals } \\
\hline & Control & VMH-lesioned & Force-fed & $\begin{array}{l}\text { Statistical } \\
\text { significance }\end{array}$ \\
\hline $\begin{array}{l}\text { Liver weight }(\mathrm{g}) \ldots \ldots \\
\text { Liver weight }(\mathrm{p} .100 \mathrm{LW}) \ldots \\
\text { Empty intestine : duodenum } \\
+ \text { intestine }+ \text { caecum } \\
\text { (p. } 100 \text { of } \mathrm{LW}) \ldots \ldots \ldots \\
\text { Heart (p. } 100 \text { of } \mathrm{LW}) \ldots \ldots \\
\text { Pancreas }(p .100 \text { of } \mathrm{LW}) \ldots \\
\text { Thyroids }(p .100 \text { of } \mathrm{LW}) \ldots \\
\text { Adrenals (p. } 100 \text { of } \mathrm{LW}) \ldots\end{array}$ & $\begin{aligned} & 12.36 \pm 2.63 \\
& 6.79 \pm 0.79 \\
& 1.34 \pm 0.40 \\
& 110.91 a \pm 24.36 \\
& 164.26 a \pm 34.33\end{aligned}$ & $\begin{aligned} 11.96 & \pm 3.39 \\
6.15 & \pm 0.83 \\
1.39 & \pm 0.40 \\
: 85 a b & \pm 33.35 \\
116.57 b & \pm 24.86\end{aligned}$ & $\begin{array}{r}14.63 \pm 3.41 \\
6.05 \pm 0.56 \\
1.38 \pm 0.41 \\
78.68^{b} \pm 23.08 \\
157.08^{a} \pm 28.68\end{array}$ & $\begin{array}{l}\text { NS } \\
\text { NS } \\
\text { NS } \\
* \\
* *\end{array}$ \\
\hline
\end{tabular}

\section{Discussion.}

Electrolytic lesion of the goose ventromedian hypothalamus induced hyperphagia, thus causing considerable obesity. This hyperphagia seemed much more marked than in the rat given the same treatment (Brobeck, Tepperman and Long, 1942, 1943). In the chicken, however, Lepkovsky and Yasuda (1966) mentioned hyperphagia when there was none since the chickens became obese without overeating. These authors believed that, as in the rat (Kennedy, 1953), this ponderal gain was essentially the result of an increase in body lipid depots ; our results confirm this. Indeed, affer treatment, the total amount of body fat was clearly higher $(\mathrm{P}<0.001)$. 
A difference in the treatments is evidenced by the difference in cover fat, which was found in increasing amounts in the control, force-fed and operated groups, respectively. However, the percentage of internal, and especially mesenteric, fat was higher at the end of forced-feeding since it reached 29 p. 100 as against 14 p. 100 in operated geese. It is to be wondered if these differences would have occurred or developed if the experimental time-course had been varied. As observed in the obese chicken with hypothalamic lesions (Lepkovsky and Yasuda, 1966), the carcass lipid distribution in our study was regular since the external fat/internal fat ratio did not vary significantly among the three groups.

According to Snapir (1976), ponderal liver gain after VMH lesion is mainly due to the large augmentation of hepatic fats which is identical to that found after forcedfeeding. This development seems normal since the bird liver is considered as the principal site of lipogenesis (O'Hea and Leveille, 1969). Therefore, any overeating should cause a quantitative increase of hepatic fat, and especially in the present study which used geese genetically selected for their ability to produce fatty livers. There did not seem to be a correlation between the weight of the liver and of the different fats, except for the external fat of the lesioned lot $(r=0.57 ; \mathrm{P}<0.1)$. However, contrary to the data of Snapir (1976), liver weight was correlated to mean daily food intake $(r=0.68 ; P<0.01)$. This relation disappeared after forced-feeding and liver weight became closely related to that of the internal fat $(r=0.84 ; P<0.001)$ as Nir, Perek and Katz (1972) already reported. Liver weight was more highly correlated to liveweight at slaughter in operated $(r=0.80 ; P<0.01)$ than in force-fed $(r=0.57$; $P<0.1)$ geese. Thus, lesioned birds fed ad libitum showed a relatively extensive liver development with fat accumulation ; the fraction released into the blood was more massively stored in subcutaneous fat. On the other hand, in geese force-fed 3 times a day, a part of the hepatic stores was preferentially evacuated towards the abdomen.

It can be supposed that for the same food intake level, adiposity develops differently depending on the feeding procedure. Snapir et al. (1976) studying the goose and other authors reporting on the rat, suggested that immediate changes in digestibility and digestive transit rhythm might occur after VMH lesion. Moreover, as in the rat, there may be divergences in the assimilation and utilization of nutriments as well as in lipogenesis with a quantitatively high increase of fat in the adipose tissues. Consequently, the lesions would appear to cause more anabolism than would forced-feeding, although the metabolism seemed to be modified in both cases.

The fatty livers obtained by electrocoagulation, while not significantly different in weight from those produced by forced-feeding, were still clearly smaller $(312 \mathrm{~g})$ than the livers obtained by the traditional method $(660 \mathrm{~g})$. The mean amounts of food ingested after $\mathrm{VMH}$ lesions (471 $\mathrm{g} /$ day) were still too low to induce the formation of fatty liver with cramming (716 g/day for 21 days). Immediately after surgery, the food intake pattern of our lesioned birds increased up to day 15 and then decreased until the end of the experiment. According to Lepkovsky (1973) studying chickens, a new «set-point 》 is established at that time, as Kennedy (1953) studying rats also showed. In traditional forced-feeding, the food intake augments up to the end of cramming, and the diet offered is different from the one used in our study.

This indicates that, as in the rat, the electrolytic destruction of the VMH disturbs some hormonal and metabolic systems (Frohman and Bernardis, 1968 ; Frohman ef al., 
1969), thus favorizing fat depots in the liver and adipose tissue. Biochemical analyses are necessary to determine the variations in the blood constants of the treatmentrelated factors causing changes in adiposity.

Pancreas weight remained stable after treatment. However, in the rat LouisSylvestre, Ferlampin and Le Magnen (1972) showed that destruction of the VMH nuclei caused prandial and postprandial hyperinsulinemia which continued throughout the life of the animal. Nir ef al. (1972) reported that the weight of the pancreas was unaffected by forced-feeding.

Knowing that different stress reactions cause adrenal hypertrophy in birds (Sturkie, 1965), would operated geese, which become apathetic and non-agressive towards the observer, be less sensitive also to the cries of their congeners during manipulation? If so, it might explain the relatively significant reduction of their adrenal weights. On the contrary, however, it is also possible that ACTH secretion might be reduced (as shown for the somatotropic hormone after VMH lesions) thus causing adrenal hypertrophy and reduced stress reaction.

\section{Conclusion.}

Some physiological analogies may be-drawn between the rat and the goose. As in the rat and the chicken, destruction of the goose $\mathrm{VMH}$ intervenes in liveweight regulation by stimulating lipogenesis since the total amount of fat, but of no other tissue, increased considerably. As compared to forced-feeding, this development of subcutaneous fat was particularly significant. Moreover, neither metabolic and hormonal changes nor behavioral deviations resulting from $\mathrm{VMH}$ lesion affected fatty liver formation, which was insufficient for practical purposes.

In such a case, our data would indicate that the progress of hyperphagia with the premature appearance of the static phase, reducing food intake, seemed to have a negative effect. In fact, overeating continued over a longer period after 6-hydroxydopamine injection (Auffray and Gallouin, 1972 ; Auffray et al., 1973), and higher weight fatty livers were obtained.

Our data tend to implicate the whole of the hyperphagic development (amplitude and duration) rather than insufficient digestive capacity or assimilation.

Reçu en septembre 1979.

Accepté en novembre 1979.

Résumé. Les effets de l'hyperphagie hypothalamique provoquée ef du gavage ont été étudiés chez 30 oies de race landaise. Logées en cages individuelles, elles sont soumises à un cycle lumineux de $12 \mathrm{~h}$ de lumière, $12 \mathrm{~h}$ d'obscurité. 11 oies avec lésions ventromédianes hypothalamiques et 8 témoins reçoivent une alimentation od libitum tandis que le 3 e lot comporte 11 animaux gavés en pair-feeding sur les opérés. L'étude porte sur une durée de 4 semaines après une période d'adaptation aux nouvelles conditions du milieu. La consommation journalière des oies ainsi que leur gain de poids hebdomadaire sont enregistrés. Après les lésions hypothalamiques $\mathrm{VMH}$, la consommation moyenne des oiseaux augmente de 169 p. 100 de telle sorte qu'après chacun des traitements leur poids corporel s'est élevé et ils sont obèses $(p<0,001)$. Au niveau composition corporelle, le groupe lésé présente une plus grande quantité de graisse sous-cutanée $(p<0,05)$ tandis que la graisse mésentérique $(p<0,05)$ est plus abondante après gavage. Dans tous les cas le poids du foie est 
fortement accru. L'augmentation relative atteint 193 p. 100 chez les oies avec lésions VMH et $123 \mathrm{p}$. 100 chez les gavées. Néanmoins, ces valeurs sont trop faibles lorsqu'on les compare aux moyennes obtenues lors du gavage traditionnel. L'hyperphagie obtenue chez l'oie est très marquée lorsqu'on la compare à celle du rat mais elle reste insuffisante dès qu'il s'agit de produire une stéatose hépatique importante.

\section{References}

AUFFRAY P., BLUM J. C., 1970. Hyperphagie et stéatose hépatique chez l'oie après lésion du noyau ventromédian de l'hypothalamus. C. R. Acod. Sci. Paris, Sér. D, 270, 2362-2365.

AUFFRAY P., GALLOUIN F., 1971. Obésité et hyperstéatose hépatique provoquée par injection de 6-hydroxy-dopamine au niveau du cerveau de l'oie. 10e Congr. int. Zootech., Versailles, thème VII, $20-23$ juillet 1971.

AUfFRAY P., MARCILLOUX J. C., BAHY C., ALBE-FESSARD D., 1973. Hyperphagie induite chez l'oie par injections intraventriculaires de 6-hydroxydopamine. C. R. Acad. Sci. Paris, Sér. D, 276, 347-350.

BROBECK J. R., TEPPERMAN J., LONG C. N. H., 1942-43. Experimental hypothalamic hyperphagia in the albino rat. Yale $j$. Biol., 15, 831-853.

FELDMAN S. E., SNAPIR N., YASUDA M., TREUTING F., LEPKOVSKY S., 1973. Physiological and nutritional consequences of brain lesions : a functional atlas of the chicken hypothalamus. Hilgardia, 41, 605-629.

FLEURET P., 1953. La production du foie gras de volaille destiné à la consommation. Ann. Nutr. Alim., 7, 97-132.

FROHMAN L. A., BERNARDIS, L. L., 1968. Growth hormone and insulin levels in weanling rats with ventromedial hypothalamic lesions. Endocrinology, 82, 1125-1132.

FROHMAN L. A., BERNARDIS L. L., SCHNATZ J. D., BUREK L., 1969. Plasma insulin and triglyceride levels after hypothalamic lesions in weanling rats. Am. J. Physiol., 216, 1496-1501.

HETHERINGTON A. W., RANSON S. W., 1940. Hypothalamic lesions and adiposity in the rat. Anat. Rec., 78, 149-172.

KENNEDY G. C., 1953. The role of depot fat in the hypothalamic control of food intake in the rat. Proc. roy. Soc. London, Ser. B, 140, 578.

LABIE Ch., TOURNUT J., 1970 . Recherches sur les modifications histologiques et biochimiques chez les oies soumises au gavage. Cah. Méd. vét., 39, 247-261.

LECLERCQ B., DURAND G., DELPECH P., BLUM J. C., 1968. Note préliminaire sur l'évolution des constituants biochimiques du foie au cours du gavage de l'oie. Ann. Biol. anim. Bioch. Biophys., 8, 549-556.

LEPKOVSKY S., 1973. Newer concipts in the regulation of food infake. Am. J. clin. Nutr., 26, 271-284.

LEPKOVSKY S., YASUDA M., 1966. Hypothalamic lesions, growth and body composition of male chicken. Poultry Sci., 45, 582-588.

LOUIS-SYLVESTRE J., FERLAMPIN F., LE MAGNEN J., 1972. Effet de la première prise alimentaire sur l'hypersécrétion insulinique chez le rat hyperphagique après lésion hypothalamique. 41-46. In APFELBAUM M., Régulation de l'équilibre énergétique chez l'homme. Masson, Paris.

NIR I., PEREK M., KATZ Z., 1972. The influence of soy bean meal supplemented to the maize diet of forced-fed geese upon their liver organ and blood plasma components. Ann. Biol. anim. Bioch. Biophys., 12, 77-89.

O'HEA E. K., LEVEILLE G. A., 1969. Lipid biosynthesis and transport in the domestic chick (Gallus Domesticus). Comp. Biochem. Physiol., 30, 149-159.

SNAPIR N., YAAKOBI M., ROBINSON B., RAVONA H., PEREK M., 1976. Involvement of the medial hypothalamus and the septal area in the control of food intake and body weight in geese. Pharmacol. Biochem. Behav., 5, 609-615.

STURKIE P. D., 1965. Avian Physiology, 672-677 2nd. Bailliere, Tindall and Cassel, London. 